\title{
COMPARISON BETWEEN CHICKEN AND RED MEAT SHAWARMA FOOD FOR BACTERIAL CONTAMINATION
}

\author{
WAZIRA Q. SAEED ${ }^{*}$ and ISSA M. MOHAMMAD ${ }^{* *}$ \\ *Dept. of biology, Faculty of Science, Soran University, Kurdistan Region -Iraq \\ ** Dept. of Animal production, College of Agricultural Engineering Sciences, University of Duhok, \\ Kurdistan Region - Iraq
}

(Received: August 23, 2021; Accepted for Publication: September 21, 2021 )

\begin{abstract}
The present study was conducted on 100 samples of two types of Shawarma fast-food (chickens meat Shawarma and red meat Shawarma) in restaurants and Cafeterias of Soran city, Kurdistan region, Iraq; for four months during 2021. The aim of this investigation was to compare both types of Shawarma for bacterial contamination. The collected samples were transferred to the laboratory using cold box and analyzed within two hours. The samples were prepared for bacteriological analysis via observed and total viable count (TVC) of bacteria; Total coliform count, Staphylococcus bacteria count, Detecting of Salmonella and Examining culture (for identification and isolating Grams Stain bacteria). The main results were as follow; TVC bacteria percentages in chicken and red meat Shawarma were (82 vs. 94) \%, respectively; with values of $\left(9 \times 10^{4}\right.$ vs. $\left.14 \times 10^{4}\right) \mathrm{cfu} / \mathrm{g}$, respectively. The counterparts' percentages of Coliform contamination were $(10$ vs. 14$) \%$, respectively; with values of $\left(27 \times 10^{2}\right.$ vs. $\left.2 \times 10^{3}\right) \mathrm{cfu} / \mathrm{g}$, respectively. Staphylococcus aureus, Staphylococcus epidermidis, Salmonella, Shigella spp and Pseudomonas bacteria recorded $(18,12,20,24$ and 2$) \%$, respectively for both types of Shawarma. The highest positive and significant $(\mathbf{P}<\mathbf{0 . 0 1})$ correlation coefficient was found between Staphylococcus aureus and Staphylococcus epidermidis count (0.762) in chicken's Shawarma. This study discovered some dangerous types of Coliforms for the first time in Shawarma samples (Raoulttella ornithinolytica, Enterobacter hormaechei, and Aeromonas salmonicida).
\end{abstract}

KEYWORDS: Shawarma food, bacterial contamination, comparison.

\section{INTRODUCTION}

$\mathbf{N}$ on-homemade foods are often unsanitary, so sellers always minimizing meal quality in order to remain customers' attention and maximizing their profit. Therefore, humans may face a great healthy problem when they eat dirty foods. Huge number of people are fed daily from such sector, which supply different varieties of low-cost and accessible meals. Therefore, microbial origin diseases that come from food, are significantly associated with street meals (WHO, 2002). Shawarma is a Levantine Arab meal, in which lamb (red meat), chicken or other species such as turkey, beef, veal, or may mixed of them are roasted and toasted on a spit (vertical spit) or roasted on a coal (horizontal spit); Shawarma meal may be submitted on a plate or as a wrap or sandwich, but its meat is roasted only from the outside, while meat inside remains uncooked, despite the shavings are cut off part of meat for serving, and the rest meat is kept roasted on the rotating skewer (Ahmed et al., 2015). Such food often contaminated with different types of pathogens due to the open side restaurants, and also it contains a lot of sodium, which causes high blood pressure and kidney's disease (Al-Saad, 2016). In addition to high quantity of Tran's Fats, saturated Fats and / or cholesterol which can be a lethal compound affect the heart health (Hovenkamp et al., 2008).

Nowadays, the lifestyle of human has been changed and such changes appeared in human diet, their food types, cooking time...etc. These changes create another change, which is the increasing in restaurants numbers and then people's tendency to consume more fast food (Amamoto et al., 2004). The pathogens involved in Foodborne diseases (FBDs) are Salmonella spp., Vibrio parahaemolyticus, Vibrio cholerae, Staphylococcus aureus, Clostridium botulinum, Clostridium perfringens, Bacillus cereus, 
Listeria monocytogenes (Hernández-Cortez et al., 2017).

SGMRL and Gunasena, (2016) tested the Shawarma samples and assessed the rate value of TVC as ranged from (4.15 - 4.48) log cfu/g; while Salem et al., (2016) tested Shawarma sandwiches of chicken and red meat and found that the rate values of TVC were $\left(2.8 \times 10^{6}\right.$ and $\left.2.7 \times 10^{7}\right) \mathrm{cfu} / \mathrm{g}$, respectively. Kumar and Op, (2017) analyzed ready to eat meat samples and tested the value of TVC as $\left(1.8 \times 10^{6} \mathrm{cfu} / \mathrm{g}\right)$. also, while Nashwa et al., (2017) assessed the mean value of TVC as $\left(1.3 \times 10^{4} \mathrm{cfu} / \mathrm{g}\right)$. Abdalhamid et al., (2013) analyzed fifty samples of fast food Shawarma and tested the value of Staphylococcus aureus bacteria as $\left(8.3 \times 10^{3}\right.$ $\mathrm{cfu} / \mathrm{g})$ with percentage of $(36 \%)$; while Ahmed et al., (2015) assessed the Shawarma sandwiches and found that the mean value of Staphylococcus aureus of tested beef and chicken Shawarma sandwiches were $\left(5.2 \times 10^{3}\right.$ and $\left.3.6 \times 10^{3}\right) \mathrm{cfu} / \mathrm{g}$, respectively. Matos et al., (2006) reported that the analysis of meat samples resulted in estimating the percentage of (14.3\%) as Staphylococcus epidermidis. In cooked meat samples, Amin, (2015)stated that the percentage of Staphylococcus epidermidis was (47.47\%); while Salem et al., (2016) tested Shawarma sandwiches of chicken and meat, and they found that the percentages of Staphylococcus epidermidis just (4\% and 6\%), respectively. Another researcher mentioned that ready to eat Shawarma samples had content of Staphylococcus epidermidis as $\left(7.2 \times 10^{4} \mathrm{cfu} / \mathrm{g}\right)$ in Europe (Podkowik et al., 2016). However, different researchers (Khalafalla et al., 2015; Elfaki and Elhakim, 2011; Amin, 2015) indicated various coliform values in Shawarma meat which were $\left(9 \times 10^{3} ; 2.6 \times 10\right.$ and $8.14 \times 10^{2}$ CFU/g) by, respectively. Recently, El-Fakhrany et al., (2019) tested Shawarma of chicken and red meat, and reported percentages of Enterobacter cloacae as (42 \%, and $44 \%$ ), respectively; while Salem et al., (2016) indicated Enterobacter cloacae as (7\% and $10 \%)$ for the previous Shawarma respectively. Radwana, (2020) analyzed Shawarma samples and rate the percentage of Salmonella as $(8 \%)$; while Alharbi et al., (2019) were tested the percentage of Salmonella as $(15 \%)$ in Shawarma food. The aim of this investigation was to study the types of bacteria present in the collected samples and to compare both types of Shawarma for bacterial contamination.

\section{MATERIAL AND METHODS}

This study was carried out on 100 samples (equally) of two types of Shawarma food (chickens' meat and red meat Shawarma) during winter of 2021, from restaurants of Soran city, Kurdistan region, Iraq; in order to study the bacterial contamination in the collected samples, that selected randomly for the period of 4 months. The collected samples were transferred directly to the laboratory using col box $\left(0-4^{\circ} \mathrm{c}\right)$ and analyzed within two hours. The samples were sterilized using dry heat (red heat flame and flaming) and wet heat according to (Varghese \& Joy, 2014). Also, all equipment that used in this study, and all culture media were done according (Varghese \& Joy, 2014).

\section{Bacteriological Analysis}

The collected samples were diluted up to dilution of $10^{-7}$, according to (Harrigan and McCance, 1987).

\section{Counting and detecting}

Total viable count (TVC), Total Coliform, Staphylococcus and Salmonella were counted and detected also according to (Harrigan and McCance, 1987).

\section{Examination of culture}

All solid culture media were examined for growth, pigmentation, colony morphology and media alterations. Plates with evident growth were submitted to further bacteriological testing. Those who did not demonstrate apparent development were incubated for a longer period of time; if no growth was identified after 48 hours, the sample was discarded. However, identification of isolated bacteria was done according to (Varghese \& Joy, 2014); and secondary identification (vitex test) done according to (Pincus, 2006).

\section{Statistical Analysis}

The collected data were submitted to SPSS software (SPSS, 2019) and different procedures were applied (Descriptive statistics, Frequencies and Correlation coefficients).

\section{RESULTS AND DISCUSSION}

\section{Total viable count}

The results show that the bacterial contamination in chicken's samples is (82 \%) and in red meat ones is (94\%) as illustrated in (Table 1 and Figure 1). Also, the mean value of TVC bacteria in chicken meat samples is $\left(9 \times 10^{4}\right.$ $\mathrm{cfu} / \mathrm{g})$, while in red meat samples is higher $\left(14 \times 10^{4} \mathrm{cfu} / \mathrm{g}\right)$ as shown in (Table 2 and Table $3)$. 
Table (1:) Percentages of bacterial contamination in chicken and reds' meat Shawarma

\begin{tabular}{cccccccc}
\hline & $\begin{array}{c}\text { Total } \\
\text { viable } \\
\text { count }\end{array}$ & $\begin{array}{c}\text { Total } \\
\text { colifor } \\
\mathbf{m}\end{array}$ & $\begin{array}{c}\text { Staphylococc } \\
\text { us aureus }\end{array}$ & $\begin{array}{c}\text { Staphylococcu } \\
\text { s epidermidis }\end{array}$ & Salmonella & Shigella & $\begin{array}{c}\text { Pseudomona } \\
\text { s }\end{array}$ \\
\hline $\begin{array}{c}\text { Shawarma's } \\
\text { chicken meat }\end{array}$ & 82 & 10 & 18 & 12 & 20 & 24 & 2 \\
\hline $\begin{array}{c}\text { Shawarma's } \\
\text { red meat }\end{array}$ & 94 & 14 & 18 & 12 & 20 & 24 & 2 \\
\hline
\end{tabular}

However, the present results of TVC bacteria from chicken and red meat Shawarma samples are similar to that obtained by (Alsaiqali, 2006; Elfaki and Elhakim, 2011). Moreover, the present results of TVC in both chicken and red meat Shawarma are disagreement with that reported by (Tavakoli and Riazipour, 2008; Yuksek et al., 2009). Despite the preparation of Shawarma needs to expose to heating, there were still pathogenic microorganisms observed on the studied samples. So, such result may reflect the fact that some of the observed microorganism can be survive in high cooking temperature which is not sufficient to eliminate harmful microorganisms, or the high contamination of bacteria in Soran city samples, may be attributed to the improper washing, packing and handling, in addition to dusty of the area throughout the preparation process and during the exhibition.

As shown in Tables $(2 \& 3)$, the counts of bacteria were not distributed normally among the studied samples, due to the values of skewness that exceeded zero, and high standard deviations. These results ensure that the studied samples had not homogeneity in their counts of different types of bacteria. But in general, such counts of bacteria are relatively high and dangerous on human health. Some samples had not specific types of bacteria, but had a huge count of another types of bacteria; and vice versa, for both studied types of Shawarma.

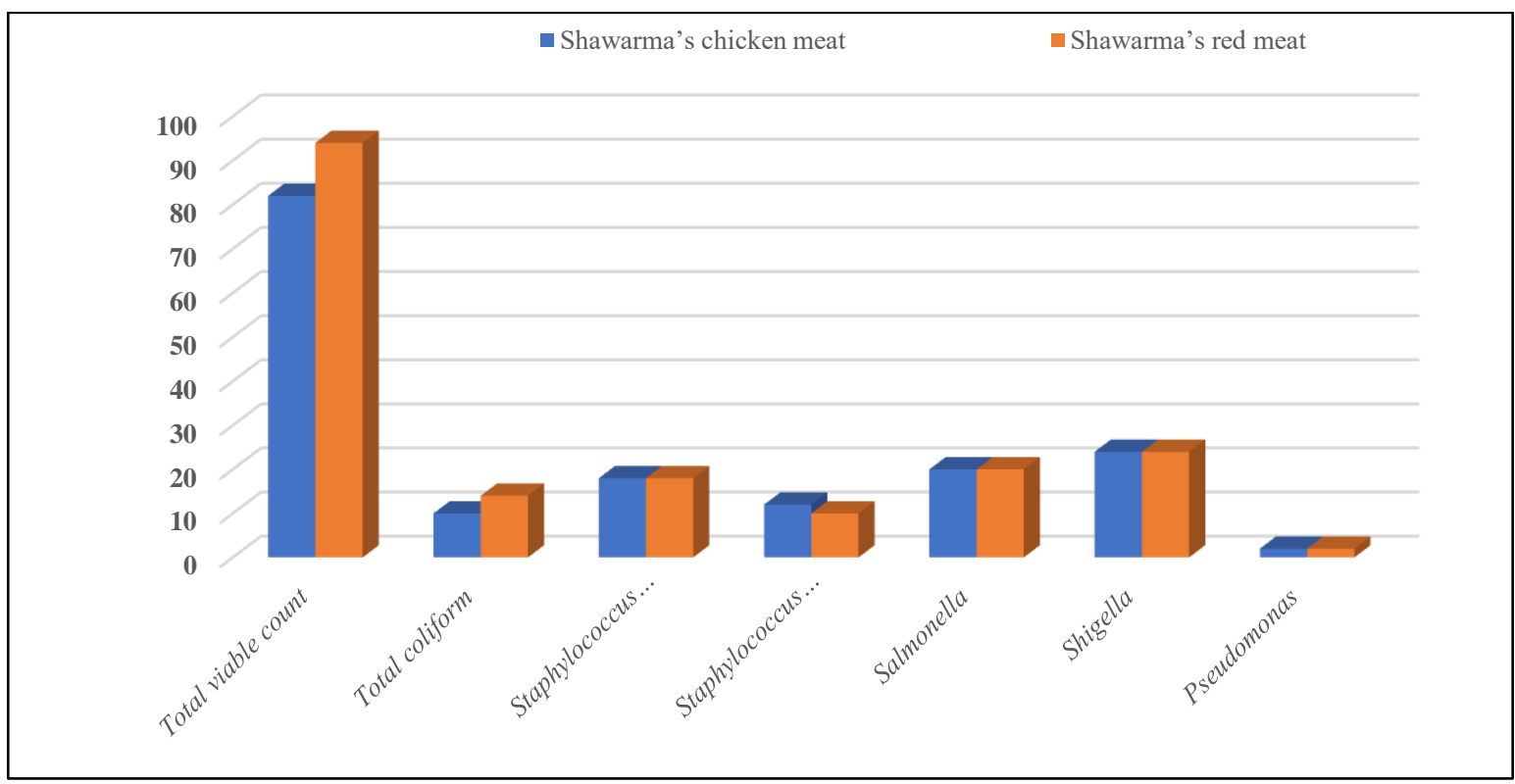

Fig. (1): Bacterial contamination (\%) of chicken vs. red meat Shawarma 
Table (2): Descriptive statistics of bacteria in chicken's Shawarma meat

\begin{tabular}{lccccc}
\hline & Minimum & Maximum & Mean & Standard Error & Skewness \\
\hline Total viable count & 0 & $35 \times 10^{4}$ & $9 \times 10^{4}$ & $16 \times 10^{3}$ & 1.15 \\
\hline Total coliform & 0 & $45 \times 10^{3}$ & $27 \times 10^{2}$ & $13 \times 10^{2}$ & 3.58 \\
\hline Staphylococcus aureus & 0 & $2 \times 10^{4}$ & $17 \times 10^{2}$ & $6 \times 10^{2}$ & 3.05 \\
\hline Staphylococcus epidermidis & 0 & $6 \times 10^{3}$ & $5 \times 10^{2}$ & $2 \times 10^{2}$ & 2.73 \\
\hline
\end{tabular}

Table (3): Descriptive statistics of bacteria in red meat's Shawarma

\begin{tabular}{lccccc}
\hline & Minimum & Maximum & Mean & Standard Error & Skewness \\
\hline Total viable count & 0 & $6 \times 10^{5}$ & $14 \times 10^{4}$ & $22 \times 10^{3}$ & 0.99 \\
\hline Total coliform & 0 & $6 \times 10^{4}$ & $2 \times 10^{3}$ & $12 \times 10^{2}$ & 6.05 \\
\hline Staphylococcus aureus & 0 & $26 \times 10^{3}$ & $1 \times 10^{3}$ & $5 \times 10^{2}$ & 5.23 \\
\hline Staphylococcus epidermidis & 0 & $1 \times 10^{4}$ & $3 \times 10^{2}$ & $2 \times 10^{2}$ & 5.60 \\
\hline
\end{tabular}

\section{Isolation of Total Coliform}

Assessing the studied Shawarma samples, resulted in determining the percentage of Coliform contamination in chicken meat as $(10 \%)$ and in red meat as higher $(14 \%)$ as shown in (Table 1 and Figure 1). Moreover, the results of mean value of coliform in chicken meat (927 $\mathrm{x} 102 \mathrm{cfu} / \mathrm{g})$ and in red meat $(2 \times 103 \mathrm{cfu} / \mathrm{g})$ are shown in tables (1 and 2)

However, the present findings are disagreement with the results of (Abdalhamid et al., 2013), for Coliform percentage in red meat Shawarma, where the last author recorded higher value. Also the present finding of red meat Shawarma was recorded higher value than the result of (Ahmed et al., 2015). In general, the results that reported by (Tavakoli and Riazipour, 2008) were recorded less values of Coliform in comparison to the findings of the present study. The relative high values of the present findings may be attributed to the slaughtering process and slaughter house cleaning, in which the meat samples were exposed to different sources of contamination, such causes consider additional reasons for the bacterial contamination in the studied restaurants in Soran city. In general, careful handling of cooked Shawarma and maintenance of adequate cooling temperature during storage would reduce Coliform and enhance the shelf life of Shawarma.

The results of diagnosing isolated coliform bacteria are belong to the following species (Enterobacter cloacae ssp cloacae 60\%, Raoulttella ornithinolytica $20 \%$ and Enterobacter hormaechei 20\%), while all
Coliform isolates in meat Shawarma were belonged to Aeromonas salmonicida as shown in (Table 4 and Figure 2).

The present findings are in agreement with the results of (Hasan, 2014; El-Fakhrany et al., 2019) for Enterobacter cloacae organism in chicken's Shawarma.

The present findings are disagreement with the results of (Salem et al., 2016) for Enterobacter cloacae in chicken's Shawarma analysis; and also disagreement with the analyzed samples by (Ismail, 2006; Mohammed, 2010; Abdalhamid et al., 2013; Amin, 2015) for Enterobacter cloacae in red meat Shawarma samples. However, Ismail Hakkı Tekiner, (2015) reported values similar to the present investigation results in regard to the red meat Shawarma samples.

These mentioned bacteria are among the most common bacteria that cause disease, therefore the presence of such organisms in ready-to- eat food (Shawarma) describes an awful state of poor hygiene and unsanitary practices employed in the processing and packaging of this food product.

The contamination reasons of the studied samples of the mentioned bacteria may related to the restaurants that kept or stored food in open places within an environmental temperature $\left(30-40^{\circ} \mathrm{C}\right)$, which is favorable for microbial growth; and also, none of the restaurant workers have had training on hygienic food preparation and handling practices. 
Table (4). Species of coliform isolates from chicken and reds meat Shawarma

Coliform

\begin{tabular}{lcccc}
\cline { 2 - 4 } & $\begin{array}{c}\text { Enterobacter } \\
\text { cloacae ssp } \\
\text { cloacae }\end{array}$ & $\begin{array}{c}\text { Raoulttella } \\
\text { ornithinolytica }\end{array}$ & $\begin{array}{c}\text { Enterobacter } \\
\text { hormaechei }\end{array}$ & $\begin{array}{c}\text { Aeromonas } \\
\text { salmonicida }\end{array}$ \\
\hline Chicken's Shawarma & 60 & 20 & 20 & 0 \\
\hline Red meat Shawarma & 0 & 0 & 0 & 100 \\
\hline
\end{tabular}

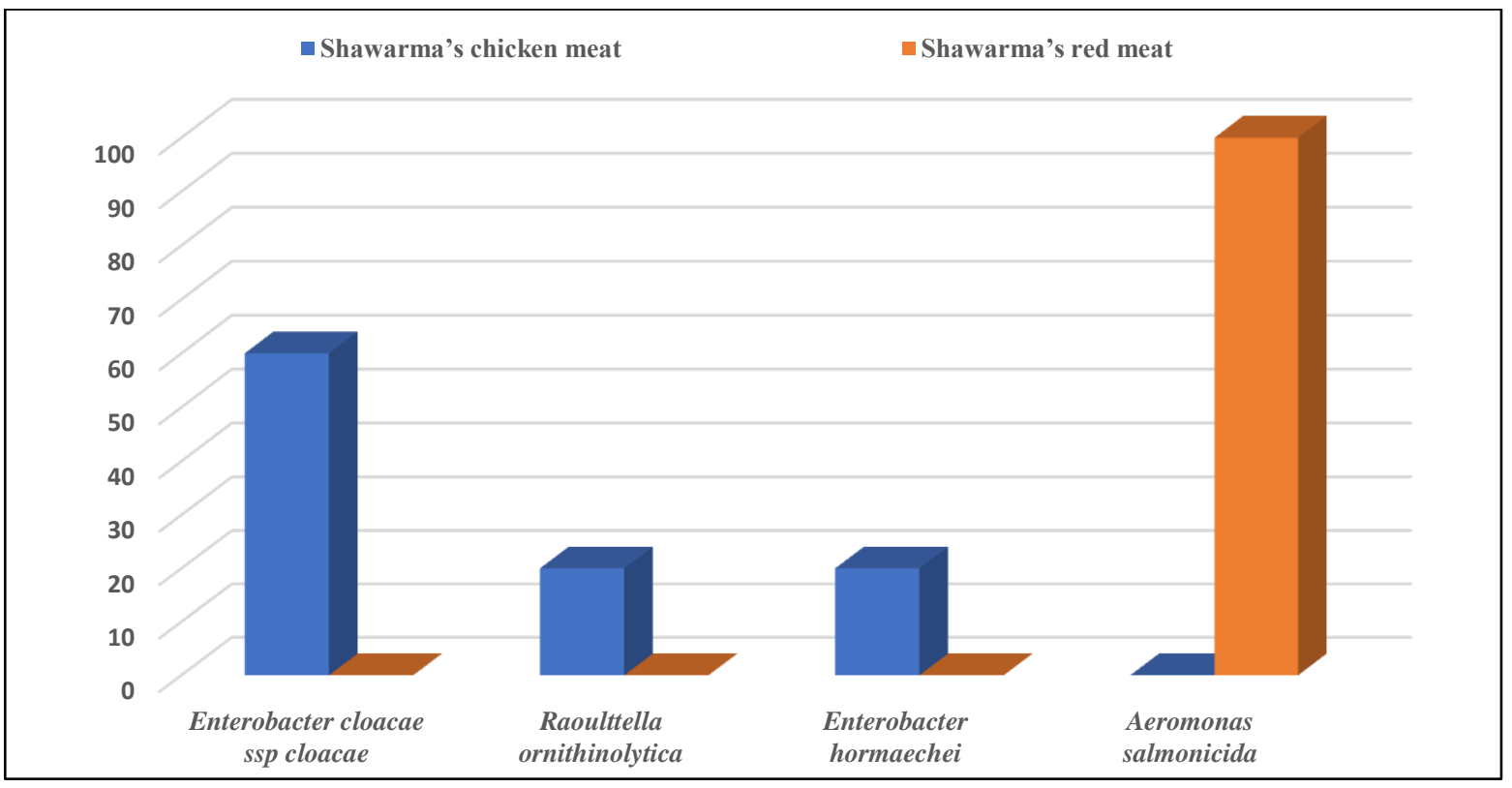

Fig. (2): Percentage (\%) of coliform isolates from chicken's and red meat Shawarma samples

\section{Isolation of Staphylococcus aureus bacteria}

The percentages of Staphylococcus aureus bacteria are shown in (Table 1 and Figure 1). The results of both chicken and red meat Shawarma samples are the same (18\%), this value is relatively low. The mean value of previous samples are $\left(17 \times 10^{2}\right.$ and $\left.1 \times 10^{3} \mathrm{cfu} / \mathrm{g}\right)$, respectively (Table 2 and Table 3 ).

The present results of chicken's Shawarma are in agreement with the results reported by (Yetim et al., 2003; Alsaiqali, 2006; Mohammed, 2010; Salem et al., 2016; AlMossawei et al., 2018; Alharbi et al., 2019; Ghonaim et al., 2020); where their results were similar and less than our results.

Also, the present findings of chicken's Shawarma are disagreement with the results indicated by (ZAKI, 2008; Al-Dughaym and Altabari, 2010; Amin, 2015; Mohamed, 2015; Radwana, 2020); where their results were not closed and higher than our results.

Regarding red meat Shawarma samples and its content of Staphylococcus aureus bacteria, the findings of this study are in agreement with the results of (Yuksek et al., 2009; Abdalhamid et al., 2013; Ahmed et al., 2015; Ragab et al., 2019); where their results were similar to our results.

Also, the present findings of red meat Shawarma are disagreement with the results of (Reginald and Gayle, 2001; Sharaf and Sabra, 2012; NASHWA et al., 2017; Morshdy et al., 2019); where their results were far than our results in percentages of Staphylococcus aureus bacteria.

However, presence of Staph. aureus bacteria in the studied samples of Shawarma meat maybe indicates the shortage in the hygiene of production. Moreover, such organisms may take the chance to cloned and replicated in the product during storage, and then produce their enter toxins which constitute a public health hazard (Staphylococcal food poisoning) to the consumers.

The contamination of studied meat samples with this type of bacteria species may increase when the workers did not wash their hands after touching any part of their body. Another reason 
of contamination, perhaps is handling and packing of food by workers, because the hands of human and also their fingers are important sources of Staphylococcus aureus contamination. In addition, Staphylococcus aureus is food handlers' bacteria, especially at nasal areas and hands which make toxigenic. Furthermore, may the employer touch his nose and continue his work. Finally, the cooked meat may be kept in an open environment, so it will cause the contamination.

\section{Isolation of Staphylococcus epidermidis bacteria}

The results of percentages of Staphylococcus epidermidis in chicken and red meat Shawarma of studied samples are the same (12\%) as shown in (Table 1 and figure 1); also, the mean value of Staphylococcus epidermidis in chicken's Shawarma is $\left(5 \times 10^{2} \mathrm{cfu} / \mathrm{g}\right)$, while the same value in red meat Shawarma is $\left(3 \times 10^{2} \mathrm{cfu} / \mathrm{g}\right)$ as shown in (Table 2 and Table 3). These values may seem to be relatively small, but it affects negatively on human health and cause diseases.

The present results are in agreement with the result that reported by (Matos et al., 2006) for chicken's meat Shawarma, and with the result that indicated by (Salem et al., 2016) for red meat Shawarma. On the other hand, the present findings are disagreement with the results that found by (Podkowik et al., 2016) and (Amin, 2015) for chicken and red Shawarma , respectively.

This investigation suggest that one of the most effective reason of meat contamination is employer, who doesn't wash his hands periodically especially after defecation. This bacterium (Staphylococcus epidermidis), often pooled in fat, so it may always found in the meat food, which lead to the meat deterioration.

\section{Isolation of Salmonella bacteria}

The results of Salmonella bacterium in both chicken and red meat Shawarma have the same percentage (20\%) as shown in (Table 1 and Figure 1). However, in case of comparison these results with the findings of different previous authors, it could be seen that the present results are in agreement with some of them and disagree with others. Also, the percentages that mentioned by the review may be less or higher than the present findings, due to different factors such as studied region and environment, type of meat and cleaning of restaurants, which cause bacterial contamination with different levels.

The present results are in agreement with those observed by (Mohammed et al., 2009;
Khalafalla et al., 2015; Amin, 2015; Kumar and Op, 2017), for chicken meat Shawarma; and disagreement with that noticed by (Nimri et al., 2014; Wei-Wei et al., 2018) for the same samples as containing Salmonella bacteria .

Regarding red meat Shawarma, the present results also are in agreement with the findings that reported by (Hasan, 2014; Ahmed et al., 2015; Hassanin et al., 2015; SABER et al., 2017). Also, the present results are disagreement with the results that indicated by (Kayisoglu et al., 2003; Harakeh et al., 2005; Nimri et al., 2014; Wei-Wei et al., 2018).

Hence, the most probable explanations for the presence of Salmonellae bacteria and other foodborne pathogens in the studied Shawarma samples may be due to the used knives during carving of meat or the contamination by food handlers.

\section{Isolation of Shigella ssp. bacteria}

The results of percentage of bacteria Shigella spp., in both chicken and red meat Shawarma are the same and equal to (24\%) as shown in (Table 1 and Figure 1). This percentage is not low and may affect negatively on the human health.

The present result is similar to the results that indicated by (Islam et al., 2015; Akusu et al., 2016; Ogunkoya and Sholotan, 2021), for both chicken and red meat Shawarma samples, where the differences between the present results and the review findings are relatively low. But, the present results are disagreement with that reported by (Juan, 2014; Fowoyo and Igbokwe; 2014; Hallaç, 2017; Rahimi et al., 2017), where their findings relatively far than the results of this study for both Shawarma sandwich types.

The present results suggested that the food leftovers should not be kept in the fridge too long time, because it can result in bacterial overgrowth including Shigella spp bacteria. Therefore, people should eat food leftovers minimum available time. If people planned to mix leftovers with other type of foods, the new meal should not be stored again as leftovers. On the other hand, the raw local meat may be held with such bacteria due to improper storage which make high contamination risk.

\section{Isolation of Pseudomonas bacteria}

The results of percentage of Pseudomonas bacteria in both chicken and red meat Shawarma are the same and equal to (2\%) as shown in (Table 1 and Figure 1). As it observe such percentage is very low compared to other noticed bacteria percentages in the studied samples. 
However, this observations are in agreement with the results that found by (Abbas et al., 2018; Mohammed, 2010), for both studied types of Shawarma, where it were similar and close to each other. On contrary, this results are disagreement with that reported by (Alsaimary, 2015; Zakki et al., 2017; Ogunkoya and Sholotan, 2021) for both studied types of Shawarma meat. Moreover, some researchers stated that Pseudomonas bacteria percentage was very high in red meat Shawarma sandwich samples (Odu and Akano, 2012; Qasim, 2019).

Some strains of bacteria can remain to survive for long periods on surfaces like utensils, cutting boards, storage containers and food manufacturing equipment. Therefore, this investigation suggested to decrease the bacterial contamination by properly wash all equipment using soap and sterilizers if possible.

\section{The relationship between bacteria strains}

The relationship between studied strains of bacteria that found in studied samples of Shawarma, was investigated by using Spearman correlation coefficients, due to unmorally distributed data of bacteria, some samples had null number or percentage and some others involved huge numbers (count) of the same bacteria. Tables (5 \& 6), present the correlation coefficients between numbers (count) of different studied strains of bacteria in chicken's and red meat Shawarma, respectively.

It could be observed from the Table 5, that the correlation coefficient between total viable count and total coliform in chicken's Shawarma is insignificant ( $p>0.05)$ and the same trend is true for the relationship between total viable count and Staphylococcus epidermidis bacteria count, while the correlation coefficient between total viable count and Staphylococcus aureus is significant $(\mathrm{p}<0.05)$ and equal to $(0.320)$, this mean that when total viable count increase it make the Staphylococcus aureus increases, the same trend could be noticed for the correlation coefficient between Total coliform and Staphylococcus aureus which is significant $(\mathrm{p}<0.05)$ and equal to $(0.321)$, this mean also that when total viable count increase it make the Staphylococcus aureus increases. However, the correlation coefficient between Total coliform and Staphylococcus epidermidis is highly significant $(\mathrm{p}<0.01)$ and equal to $(0.486)$, this mean that when total viable count increase it make the Staphylococcus epidermidis tightly increases. Also, the correlation coefficient between Staphylococcus aureus and Staphylococcus epidermidis count is highly significant $(\mathrm{p}<0.01)$ and equal to $(0.762)$, this also mean that when Staphylococcus aureus count increase in chicken's Shawarma samples it made the Staphylococcus epidermidis count tightly increases; this last result is very important, that is mean both Staphylococcus strains have association in its presence, then it may make high dangerous for human.

Table (5): Spearman correlation coefficients between the studied strains of bacteria in chicken's Shawarma.

\begin{tabular}{|c|c|c|c|c|}
\hline & Total viable count & Total coliform & Staphylococcus aureus & $\begin{array}{l}\text { Staphylococcus } \\
\text { epidermidis }\end{array}$ \\
\hline Total viable count & 1 & & & \\
\hline Total coliform & 0.177 & 1 & & \\
\hline $\begin{array}{l}\text { Staphylococcus } \\
\text { aureus }\end{array}$ & $0.320^{*}$ & $0.321^{*}$ & 1 & \\
\hline $\begin{array}{l}\text { Staphylococcus } \\
\text { epidermidis }\end{array}$ & 0.213 & $0.480^{* *}$ & $0.762^{* *}$ & 1 \\
\hline
\end{tabular}

Moreover, for red meat Shawarma, it could be observed from Table 6 , that the correlation coefficients between Total viable count and Staphylococcus aureus count is highly significant $(\mathrm{p}<0.01)$ and negative $(-0.408)$, this mean that when Total viable count is increased the count of Staphylococcus aureus is decreased, which indicate that the percentage of the last bacteria may remain low compared to other strains.

Also, the same coefficient is in the same significant level $(p<0.1)$ but positive for the 
relationship between both Staphylococcus strains (aureus \& epidermidis) and equal to (0.689), this mean that both strains are relatively related to each other as presence on the red meat of Shawarma. All other correlation coefficients between studied items are insignificant ( $p>0.05)$.

Table 6: Spearman correlation coefficients between the studied strains of bacteria in red meat Shawarma

\begin{tabular}{lccc}
\hline & Total viable count & Total coliform & $\begin{array}{c}\text { Staphylococcus aureus } \\
\text { Staphlococcus } \\
\text { epidermidis }\end{array}$ \\
\hline Total viable count & 1 & 1 & 1 \\
\hline Total coliform & 0.219 & -0.187 & $0.689^{* *}$ \\
\hline Staphylococcus aureus & $-0.408^{* *}$ & -0.134 & 1 \\
\hline Staphylococcus epidermidis & -0.240 &
\end{tabular}

** Correlation is significant at $(\mathrm{p}<0.01)$

\section{CONCLUSION}

It could be concluded from the present study, that:

High microbial loads of (Staphylococcus, Coliform, Salmonella, Shigella and Pseudomonas) were noticed in both studied types of Shawarma. This study found some other dangerous types of Coliforms for the first time in Shawarma samples (Raoulttella ornithinolytica, Enterobacter hormaechei, and Aeromonas salmonicida). Spearman correlation coefficients between most of the studied bacteria in chicken's Shawarma were significantly positive.

\section{REFERENCES}

ABBAS, A., ALOWSHESH, M., ALHDAD, A., TAJ, A. \& ALSAGAIR, H. (2018). Determination of Bacterial Contamination of Selected Shawerma Sandwiches at Fast Food Restaurants in Misurata City, Libya. Faculty of Pharmacy, Misurata University. Special Issue for The 2nd Annual Conference on Theories and Applications of Basic and Biosciences.

ABDALHAMID, S., FARJ, A. \& ALI, A. (2013). Bacterial contamination of ready to eat foods (shawarma sandwiches) in Misurata City, Libya. 2nd international conference on environment agriculture and food science Kuala Lumpur (Malaysia).

AHMED, A. M., EL-HAKEM, N. A. \& IBRAHIM, G. A. (2015). Chemical and microbial assessment of beef and chicken shawarma sandwiches in Ismailia governorate and its impact on consumer health. Egyptian Journal of Chemistry and Environmental Health, 1, 686-693.

Akusu O. M.1, Kiin-Kabari D. B.1* and Wemedo S. A. ( 2016). Microbiological quality of selected street vended foods in Port Harcourt metropolis, Rivers State, Nigeria. Sky Journal of Food Science, Vol. 5(2),, pp. 008 - 011.

AL-DUGHAYM, A. \& ALTABARI, G. (2010). Safety and quality of some chicken meat products in Al-Ahsa markets-Saudi Arabia. Saudi journal of biological sciences, 17, 3742.

AL-MOSSAWEI, M. T. M., JASIM, A. A. \& AMER, K. Z. (2018). Reducing The Microbialled Of Chicken Meat by Improving Grill Machine Design. Kufa Journal for Agricultural Sciences, 10.

AL-SAAD, E. (2016). Causes and effects of fast food. Biomed J Sci Tech Res, 5, 279-80.

ALSAIMARY, I. E. (2015). Bacterial Quality of Meat Products From Various Basrah Restaurants. Pyrex Journal of Microbiology and Biotechnology Research, Vol 1 (2), pp. 018-027.

ALHARBI, S. A., ABDEL-GHAFFAR, M. H. \& KADHER, N. R. (2019). Isolation and identification of pathogenic bacteria from ready-to-eat fast foods in Al-Quwayiyah, Kingdom of Saudi Arabia. African Journal of Food, Agriculture, Nutrition and Development, 19, 14739-14751.

ALSAIQALI, M. I. (2006). Prevalence of Salmonella, Staphylococcus aureus and E. coli O157: H7 in Shawarma Poultry Meat (Chicken and Turkey) Restaurants In Gaza Strip. Al Azhar University Gaza.

AMAMOTO, R., DOZONO, M. \& TOYAMA, K. (2004). The relationship between dietary life and indefinite complaint in female Nutrition department students. Seinan Jo Gakuin Bulletin, 3, 75-85.

AMIN, R. A. (2015). Bacteriological and Chemical Evaluation of Meat Meals in Some Egyptian Hotels. Benha Veterinary Medical Journal, 29, 80-91.

EL-FAKHRANY, A. E.-D., ELEWA, N. A. H., MOAWAD, A. A. \& EL-SAIDI, N. (2019) Microbiological Evaluation of some fast food 
sandwiches in Fayoum. Egyptian Journal of Food Science, 47, 27-38.

ELFAKI, A. E. \& ELHAKIM, S. A. A. (2011). Quality evaluation of two Sudanese street foods of animal origin. Advance Journal of Food Science and Technology, 3, 219-223.

FOWOYO, P. T. \& IGBOKWE, O. (2014). Impact of air pollution on the microbiological quality of ready to eat hawked foods sold around a cement factory in Lokoja, Nigeria. American Journal of Research Communication, 2, 138157.

Ghonaim, M.IE., Eid A.M., Elmossalami M.K. and Abdel-Naeem H.HS., (2020). Sensory, deterioration and bacteriological assessment of some ready to eat poultry products. Int $\mathrm{J}$ Vet Sci, 9(4): 568-572.

HALLAÇ, B. (2017). DETERMINATION of PREVALENCE and INCIDENCE of Salmonella spp. and Shigella spp. in SOME FOODS

IRAQ/SULAYMANIYAH/QALADZE. Siirt Üniversitesi, Fen Bilimleri Enstitüsü.

HARAKEH, S., YASSINE, H., GHARIOS, M., BARBOUR, E., HAJJAR, S., EL-FADEL, M., TOUFEILI, I. \& TANNOUS, R. (2005). Isolation, molecular characterization and antimicrobial resistance patterns of Salmonella and Escherichia coli isolates from meat-based fast food in Lebanon. Science of the Total Environment, 341, 33-44.

Harrigan, W.F. and E. M..; McCance (1987). Laboratory methods in food and dairy microbiology 7 th ed . Acad .Pr. (Lond) LTD.

HASAN, T. (2014). Microbial quality of selected sandwiches sold at fast food shops in Dhaka city. Brac University.

HERNÁNDEZ-CORTEZ, C., PALMA-MARTÍNEZ, I., GONZALEZ-AVILA, L. U., GUERREROMANDUJANO, A., SOLÍS, R. C. \& CASTRO-ESCARPULLI, G. (2017). Food poisoning caused by bacteria (food toxins). Poisoning: From Specific Toxic Agents to Novel Rapid and Simplified Techniques for Analysis, 33.

HOVENKAMP, E., DEMONTY, I., PLAT, J., LÜTJOHANN, D., MENSINK, R. P. \& TRAUTWEIN, E. A. (2008). Biological effects of oxidized phytosterols: a review of the current knowledge. Progress in lipid research, 47, 37-49.

ISLAM, S., NASRIN, N., RIZWAN, F., NAHAR, L., BHOWMIK, A., ESHA, S. A., TALUKDER, K. A., AKTER, M., ROY, A. \& AHMED, M. (2015). Microbial contamination of street vended foods from a university campus in Bangladesh. Southeast Asian J Trop Med Public Health, 46, 480-5.

ISMAIL HAKK1 TEKINER, H. Ö. (2015). Occurrence and characteristics of extended spectrum beta-lactamases-producing Enterobacteriaceae from foods of animal origin. Brazilian Journal Microbiology, 47, 444-451.

ISMAIL, S. A. (2006). Microbiological quality of hawawshy consumed in Ismailia, Egypt. Journal of food safety, 26, 251-263.

JUAN, L. (2014). Pathogenic Microbial Load Analysis of Ready-to-Eat Meat Products of Namak-Mandi Food Street Peshawar, Pakistan. Journal of Bio-Molecular Sciences (JBMS), 2, 21-27.

KAYISOGLU, S., YILMAZ, I., DEMIRCI, M. \& YETIM, H. (2003). Chemical composition and microbiological quality of the doner kebabs sold in Tekirdag market. Food Control, 14, 469-474.

KHALAFALLA, F., ABDEL-ATTY, N., ABDELWANIS, S. A. \& HANAFY, A. S. (2015). Food poisoning microorganisms in chicken broiler meat. Global Veterinaria, 14, 211-218.

KUMAR, N. \& OP, J. (2017). MOLECULAR CHARACTERIZATION AND DRUG RESISTANCE OF ENTEROPATHOGENIC BACTERIA ISOLATED FROM READY TO EAT FOOD IN LUDHIANA. Asian Journal of Pharmaceutical and Clinical Research, 131134.

MATOS, J., JENSEN, B. B., BARRETO, S. \& HOJBERG, O. (2006). Spoilage and pathogenic bacteria isolated from two types of portuguese dry smoked sausages after shelflife period in modified atmosphere package bacterias deteriorativasy patogenas aisladas de dos tipos de chorizos despues del periodo de vidadeanaquelenvasadas enatmosferas modifIcadas. Cyta-Journal of Food, 5, 165174.

MOHAMMED, A. M. (2010). Contamination of Ready to Eat Vended Food of Meat Origin with Aerobic Bacteria in Khartoum State. Master thises.

MOHAMMED, H., AWAD, E., IBRAHIM, A. \& HEMIDAN, M. (2009). Isolation and Identification of Salmonella from The Environment of Traditional Poultry Farms in Khartoum North. University of Africa Journal of Sciences (UAJS, 2, 118-125.

MORSHDY, A., HUSSEIN, M., MERWAD, A., HANAN, E. L. M. \& MOHAMED, A. (2019). Phenotypic, genotypic resistance and virulotyping of Staphylococcus aureus isolated from ready-to-eat food in Egypt. Adv. Anim. Vet. Sci, 7, 63-70.

NASHWA, M., NEHAL, M., HEGAZY, A. \& NAHLA, S. (2017). Bacteriological and molecular characterization of some pathogens from fast foods.

NIMRI, L., AL-DAHAB, F. A. \& BATCHOUN, R. (2014). Foodborne bacterial pathogens recovered from contaminated shawarma meat in northern Jordan. The Journal of Infection in Developing Countries, 8, 1407-1414.

OGUNKOYA, W. \& SHOLOTAN, K. (2021). MICROBIOLOGICAL ASSESSMENTS OF 
"SHAWARMA" A READY TO EAT STREET FOOD IN IGBESA, OGUN STATE, NIGERIA. Federal Polytechnic Ilaro Journal of Pure And Applied Science, 3, 08-13.

ODU, N. \& AKANO, U. (2012). The microbiological assessment of ready-to-eat-food (Shawarma) in Port Harcourt City, Nigeria. Nat Sci, 10, 18.

PINCUS, D. H. (2014). "Microbial identification using the bioMérieux Vitek® 2 system. bioMérieux, Inc. Hazelwood, MO, USA.

PODKOWIK, M., SEO, K. S., SCHUBERT, J., TOLO, I., ROBINSON, D. A., BANIA, J. \& BYSTRON', J. (2016). Genotype and enterotoxigenicity of Staphylococcus epidermidis isolate from ready to eat meat products. International journal of food microbiology, 229, 52-59.

QASIM, D. (2019). Molecular Detection of Pseudomonas Aeruginosa Isolated From Minced Meat And Studies The Pyocyanin Effectiveness On Pathogenic Bacteria. Iraqi Journal of Agricultural Sciences, 50.

RADWANA, A. G. (2020). Evaluation of Antagonistic Activity of An Egyptian Probiotic Lactobacillus plantarum Against Bacteria Isolated from Ready to Eat Meat Products Aya G. Radwana, Aziza M. Hassana, Abeer A. Shahbab, and Wageih S. El-Naghy.

RAGAB, M. M., TOLIBA, A., GALAL, G. \& ABO ELMAATY, S. (2019). Physicochemical and microbiological properties of some meat products in Sharkia governorate, Egypt. Zagazig Journal of Agricultural Research, 46, 81-90.

RAHIMI, E., SHIRAZI, F. \& KHAMESIPOUR, F. (2017). Isolation and study of the antibiotic resistance properties of Shigella Species in meat and meat products. Journal of Food Processing and Preservation, 41, e12947.

REGINALD, W. B. \& GAYLE, A. L. (2001). Bacteriological Analytical Manual. Food and Drug Administration. 8th Edition, Detection and enumeration of Staphylococcus aureus in food. AOAC International, Arlington, VA.

SABER, A., HANAA, R. E. \& SALWA, A. H. (2017). Study on some enteropathogens of street vended meat meals.

SALEM, N. I., EL GAMEL, A. M., KHALIFA, A., ABD-EL-HADY, H. A. \& ABOU ZEID, M. A. (2016). Microbial status of shawarma sandwiches in Kafr El-Sheikh Governorate. Alexandria Journal for Veterinary Sciences, 51.

SGMRL, W. \& GUNASENA, G. (2016). Microbiological quality of ready-to-eat meat based food available in temporary food outlets in Gall Face Green, Colombo, Sri Lanka. International Journal of Agriculture Forestry and Plantation, 4, 38-44.

SHARAF, E. M. \& SABRA, S. M. (2012). Microbiological loads for some types of cooked chicken meat products at Al-Taif Governorate, KSA. World Applied Sciences Journal, 17, 593-597.

SPSS. (2019). Statistical Package for Social Sciences, data analysis software, user's guid, Ver. 26, IBM publication.

TAVAKOLI, H. R. \& RIAZIPOUR, M. (2008). Microbial quality of cooked meat foods in Tehran University's Restaurants. Pakistan Journal of Medical Sciences, 24, 595-599.

VARGHESE, N. \& JOY, P. P. (2014). Microbiology Laboratory Manual. 4. Pineapple Research Station (Kerala Agricultural University), Vazhakulam-686 670, Muvattupuzha, Ernakulam, Kerala.

WEI-WEI, L., ZHU, J., ZHEN, S., LIANG, X., JIANG, Y. \& NING, L. (2018). Analysis of foodborne disease outbreaks in China mainland in 2011. Chin J Food Hygiene, 30, 283-8.

WHO, A.( 2002). WHO global strategy for food safety. Lower risk diet for better health.

YETIM, H., GONULALAN, Z., OCKERMAN, H. W. \& CHEN, M. (2003). Chemical, microbiological and sensory characteristics of doner kebab made from sucuk dough, dry fermented Turkish sausage. 49th International Congress of Meat Science and Technology, 423-424.

YUKSEK, N., EVRENSEL, S. S., TEMELLI, S., ANAR, S. \& SEN, M. C. (2009). A microbiological evaluation on the ready-to-eat red meat and chicken donair kebabs from a local catering company in Bursa. J Biol Environ Sci, 3, 7-10.

ZAKI, A. M. (2008). Occurrence of Staphylococcus aureus in fast food with special reference to its enterotoxigenicity. Animal Health Research Institute., Vol. 54 No. 117, 1-14. 